\title{
KOMPOR BERBAHAN BAKAR OLI BEKAS (KOALISI) SEBAGAI ENERGI ALTERNATIF RUMAH TANGGA
}

\author{
${ }^{1 *}$ Yohanes Jakri, ${ }^{2}$ Helmina Oktaviana, ${ }^{3}$ Efram Igrenino Rahmat, ${ }^{4}$ Vitriana \\ Reku Raja, ${ }^{5}$ Yoseph Copertino Seso \\ Universitas Katolik Indonesia Santu Paulus, Ruteng, Nusa Tenggara Timur, \\ Indonesia

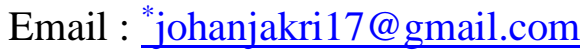

\begin{abstract}
Manuskrip: September -2021; Ditinjau: September -2021; Diterima: Oktober -2021;
Online: Januari-2022; Diterbitkan: Januari-2022
\end{abstract}

\begin{abstract}
ABSTRAK
Pandemi Covid-19 sangat berdampak pada kehidupan masyarakat khususnya di bidang ekonomi. Semenjak pandemic Covid 19 melanda Indonesia terjadi, Badan Pusat Statistik mencatat, terjadi inflasi 0,07\% pada tahun 2020. Inflasi ini tentu berawal dari turunnya daya beli masyarakat yang merupakan dampak dari ketidakstabilnya ekonomi. Hal ini tentu berpengaruh terhadap pemenuhan kebutuhan individu maupun rumah tangga. Kebutuhan akan minyak tanah sebagai bahan baku memasak menjadi salah satu kebutuhan pokok yang harus dipenuhi. Tujuananya membuat Kompor Api berbahan baku limbah oli bekas untuk keperluar rumah tangga dan industry rumah tangga dan mengetahui tingkat efektivitas limbah oli bekas untuk pembuatan Kompor Api. Metode pelaksanaan menggunakan Model pengembangan 4-D (Four D). Model ini dikembangkan oleh S. Thiagarajan, Dorothy S. Semmel, dan Melvyn I. Semmel yang tterdiri atas 4 tahap utama yaitu: Define (Pendefinisian), Design (Perancangan), Develop (Pengembangan) dan Disseminate (Penyebaran). Bahan baku KALIS adalah oli bekas kendaraan yang sudah tidak dipakai lagi. Oli bekas kendaraan ini banyak didapatkan di dealer kendaraan, bengkel-bengkel pinggir jalan, dan lain-lain, hal ini tentu menekan post pengeluaran rumah tangga, karena bahan baku yang digunakan sangat mudah ditemukan. Kompor berbahan bakar oli bekas ini sudah dipakai dalam industry rumah tangga dan sudah mulai dipasarkan dalam skala kecil.
\end{abstract}

\section{Kata Kunci: Kompor Oli Bekas, Masyarakat, Pandemi Covid 19}

\section{PENDAHULUAN}

Pandemi Covid-19 memberi dampak pada berbagai sendi kehidpuan masyarakat. Salah satu dampak yang paling dirasakan secara langsung adalah dampak ekonomi. Semenjaka pandemic Covid 19 melanda Indonesia terjadi Badan Pusat Statistik (BPS) mencatat, terjadi inflasi 0,07\% pada Oktober 2020, setelah tiga bulan berturut-turut, Juli-September, mengalami deflasi masing-masing sebesar $0,10 \%, 0,05 \%$, dan 0,05\%. Sedangkan sepanjang tahun 2020 Badan Pusat Statistik (BPS) mencatat inflasi 1,68 persen. Angka ini menjadi inflasi terendah 
sejak 2014 lalu atau selama enam tahun kebelakang. Inflasi ini tentu berawal dari turunnya daya beli masyarakat yang merupakan dampak dari ketidakstabilnya ekonomi masyarakat. Penurunan daya beli masyarakat tentu berpengaruh terhadap pemenuhan kebutuhan individu maupun kebutuhan rumah tangga.

Minyak tanah disebut juga dengan kerosene merupakan bahan bakar jenis distilat yang tidak berwarna (jernih). Penggunaan minyak tanah pada umumnya adalah untuk keperluan industri (seperti solvent) dan sebagian masih digunakan sebagai bahan bakar di rumah tangga (memasak, penerangan, dll). Memasak adalah salah satu aktivitas rumah tangga yang menjadi salah satu item pengeluaran tetap dalam rumah tangga. Kebutuhan akan minyak tanah sebaga bahan baku memasak tidak dipungkiri menjadi salah satu kebutuhan pokok yang harus dipenuhi di masa pandemic ini. Minyak tanah menjadi satu-satunya bahan baku untuk memasak, baik dalam skala rumah tangga maupun dalam skala usaha mikro. Penggunaan minyak tanah ini cukup menguras kantong, mengingat harga minyak tanah menvapai 6000/ liter. Ditengah tingginya harga minyak tanah dan menurunnya daya beli, hal ini menjadi salah satu besar dalam masyarakat.

\section{METODE PELAKSANAAN KEGIATAN}

\section{Kajian Materi}

Tahap ini merupakan tahap awal yang bertujuan untuk mencari sumber dan sharing knowledge terkait proses pembuatan KALIS.

2. Design Prototipe Kalis

Hasil sharing kwoledge kalis kemudian diterjemahkan dalam bentuk gambar dan desain pembuatan KALIS.

Bahan yang digunakan adalah:

- pipa ukuran 2 dim 1 meter,

- pipa ukuran $1 / 2 \operatorname{dim} 1$ meter,

- serigen ukuran 5 liter sebagai penampung oli bekas 1 buah,

- selang $1 / 2 \operatorname{dim} 1$ meter,

- besi plat setebal $1 \mathrm{~cm}$ yang kemudian dipotong menjadi ukuran $15 \mathrm{~cm} 5$ buah,

- blower keong 2 dim 1 buah dan

- pangkuan blower keong.

Alat yang dipakai:

- Mesin Las

- Gerinda Potong

- Kawat las LB 2.0

- Pisau Gerinda Potong

- Pisau Gerinda Tebal

- Kaca mata Las

3. Penyempurnaan dan Finalisasi Desain

a. Desain Prototpe dan alur kerja 
Desain Kalis harus menjawab kebutuhan masyarakat dan proses pembuatannya tidak membutuhkan alat dan bahan yang sulit terjangkau. Pada tahap ini juga dilakukan proses uji coba setelah pembuatan.

Adapun alur kerjanya sebagai berikut:

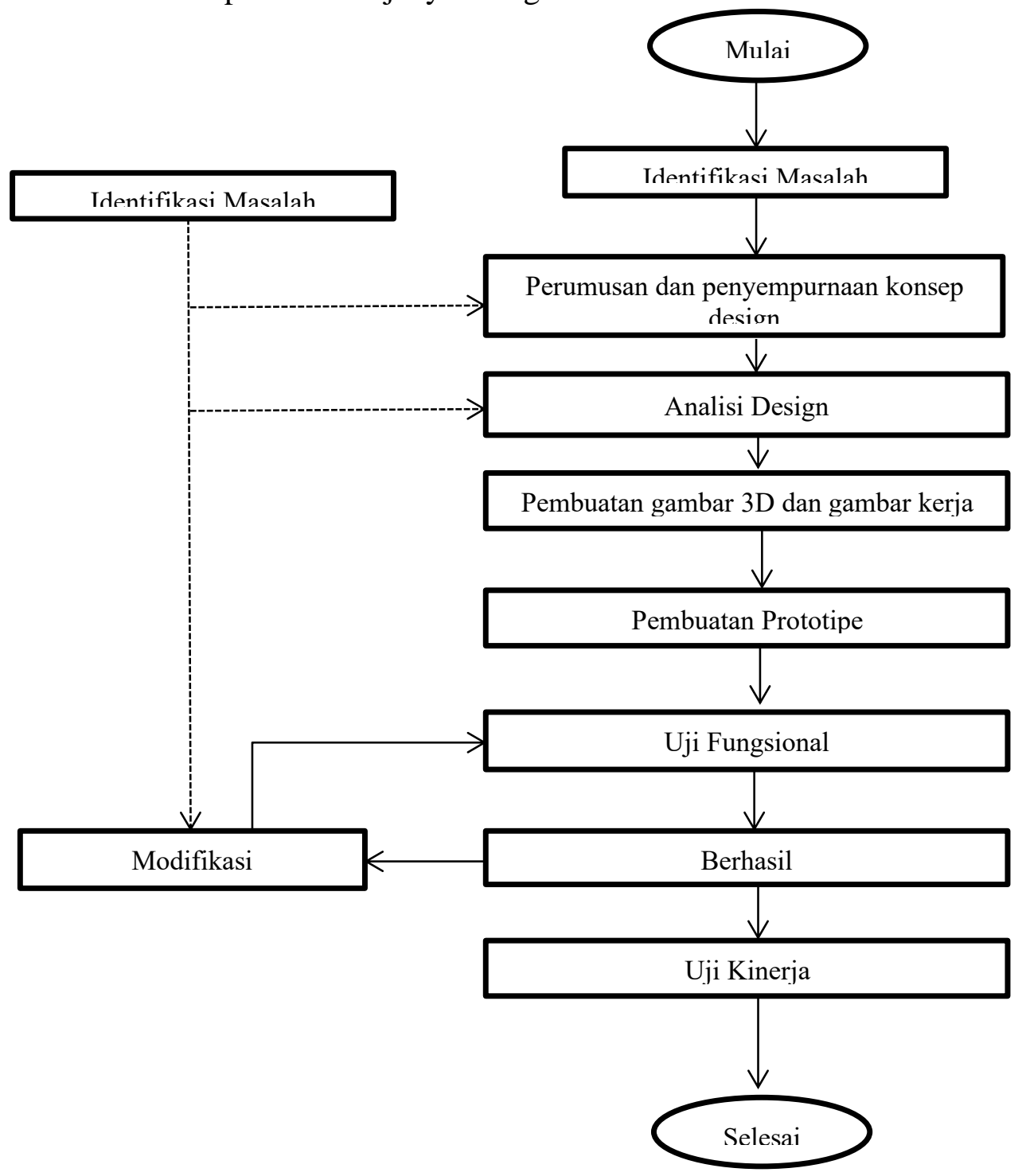

Gambar 1. Digram alur motode pelaksanaan program 
b. Proses Pengerjaan

- Langkah 1

Potong besi platsetebal $1 \mathrm{~cm}$ dengan ukuran 25 x $10 \mathrm{~cm}$ sebanyak 4 keping dan ukuran 10 x $10 \mathrm{~cm} 1$ keping

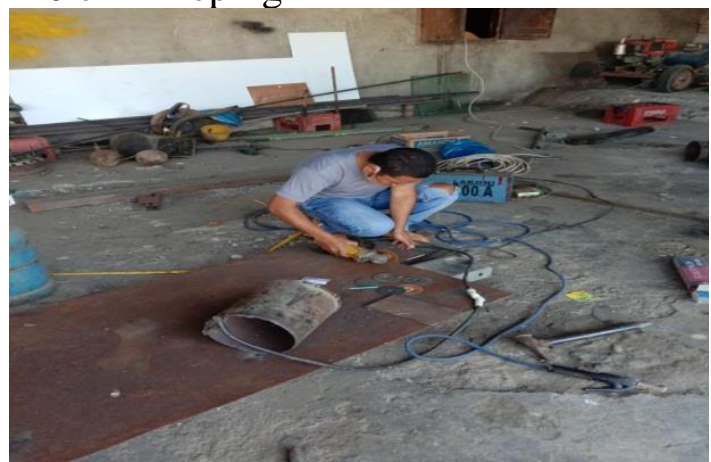

- Langkah 2

Sambungkan ke 4 potongan besi plat diatas menjadi sebuah kotak dengan menggunak las listrik

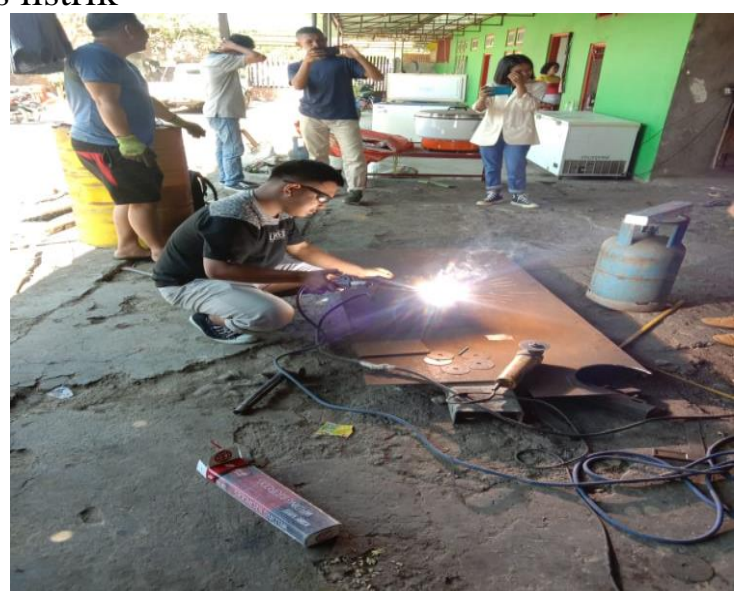

- Langkah 3

Potong pipa 2 dim sepanjang 1 meter menggunakan gerinda potong

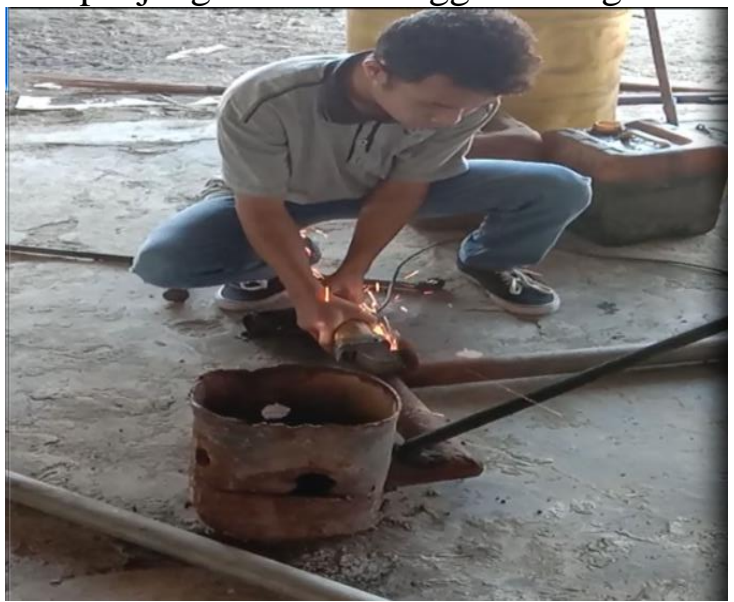


- Langkah 4

Potong pipa $1 / 2$ dim sepanjang 1 meter

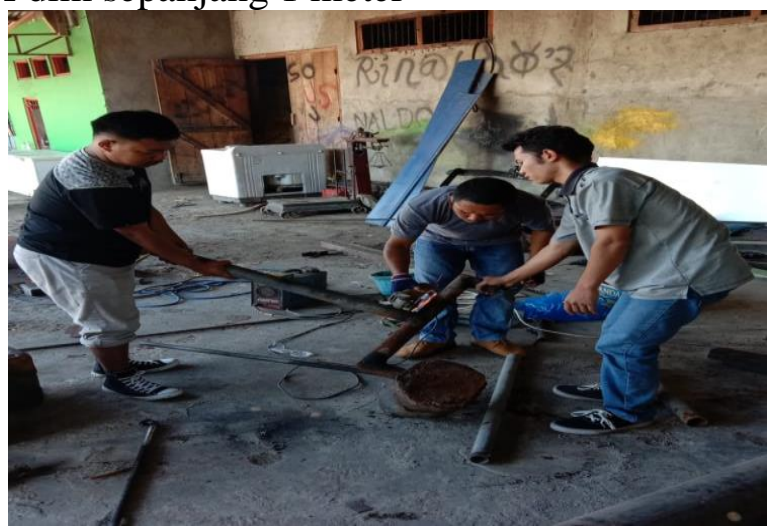

- Langkah 5

Bersihkan bekas las pada kotak tungku dengna menggunakn gerinda tebal seperti pada gambar berikut.

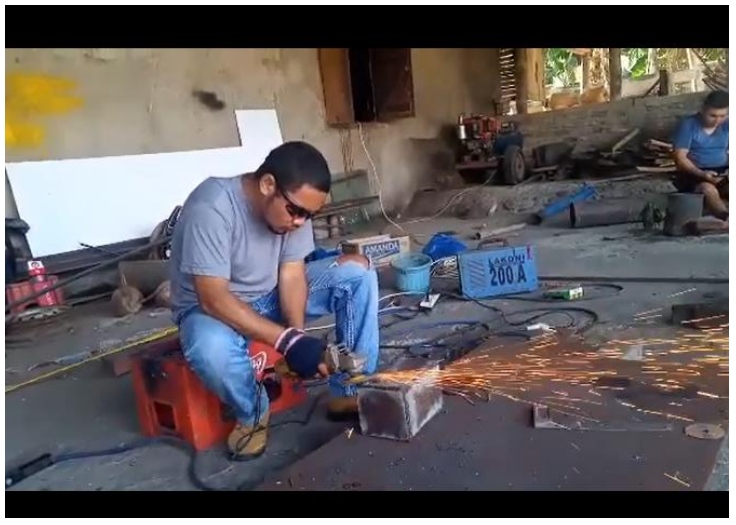

- Langkah 6

Sambungkan pipa ukuran 2 dim dan $1 / 2$ dim pada kotak besi plat dengan menggukan las listrik seperti pada gambar berikut.

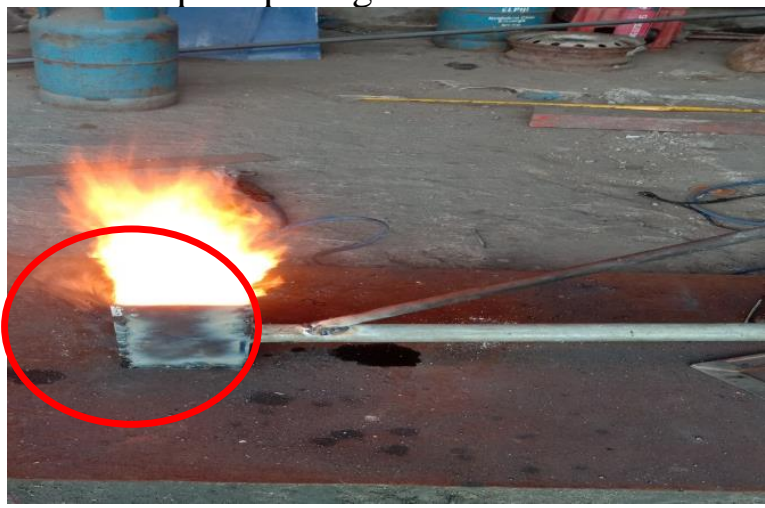

- Langkah 7

Las Pangkuan blower 2 dim pada ujung lain pipa 2 dim, seperti pada gambar berikut. 


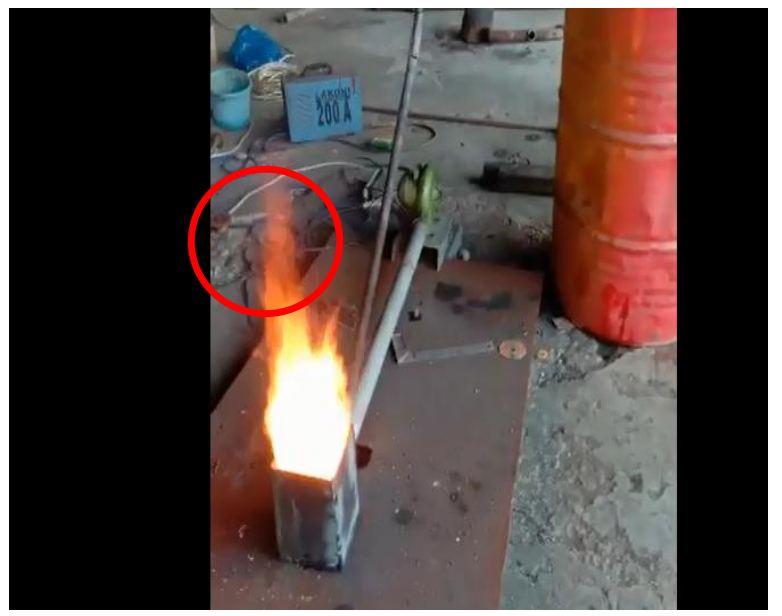

- Langkah 8

Sambungkan dan letakn Blower listrik ukuran 2 dim pada ujung lain pipa 2 dim dan pada pangkuan yang sudah di las.

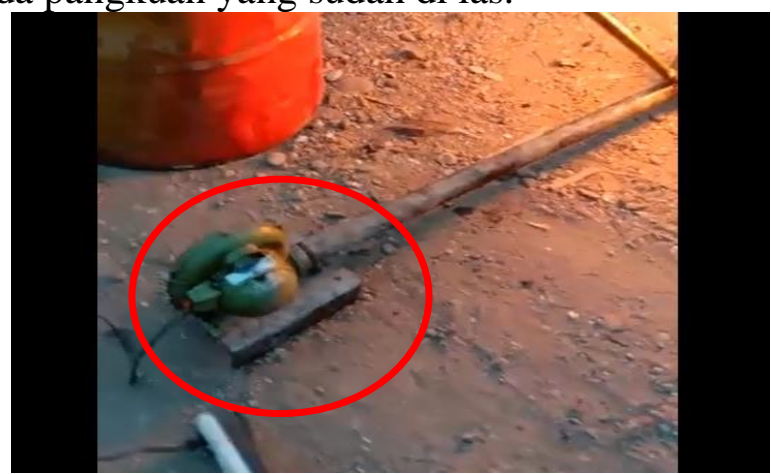

- Langkah 9

Sambungkan selang $1 / 2$ dim pada keran oli yang terhubung dengan serigen 5 liter berisi oli bekas.

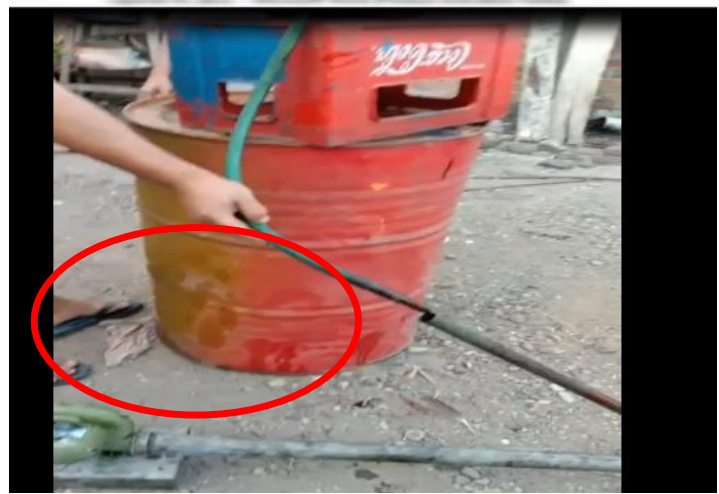

- Langkah 10

Buka klep keran dan alirkan oli secara perlahan melalui selang yang terhubung dengan pipa. 


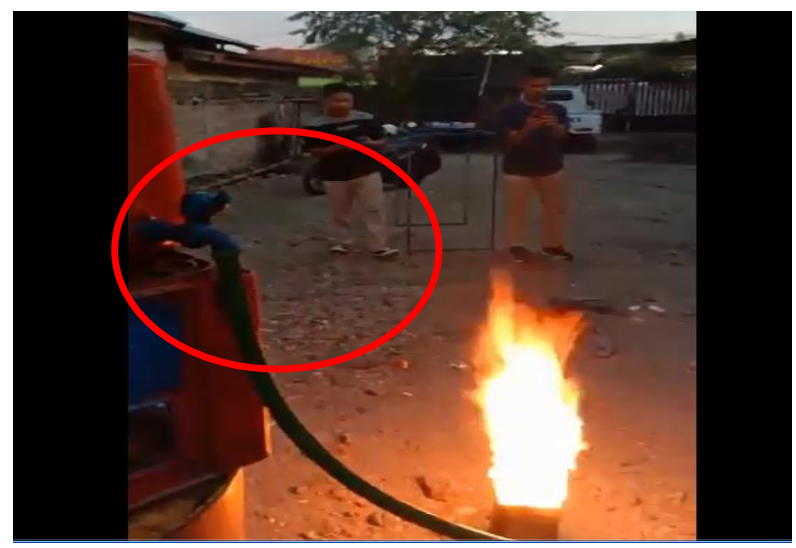

- Langkah 11

Tuangkan sedikit oli dan bensin pada tungku untuk memanaskan tungku, lalu nyalakan api menggunakan kertas.

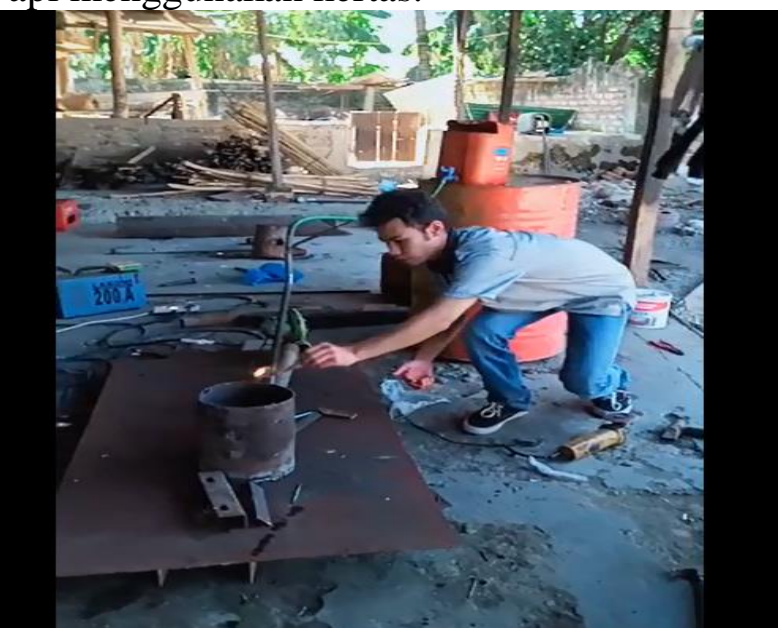

- Langkah 12

Setelah api pada tungku menyala sempurna, nyalakan blower listrik, seperti pada gambar berikut.

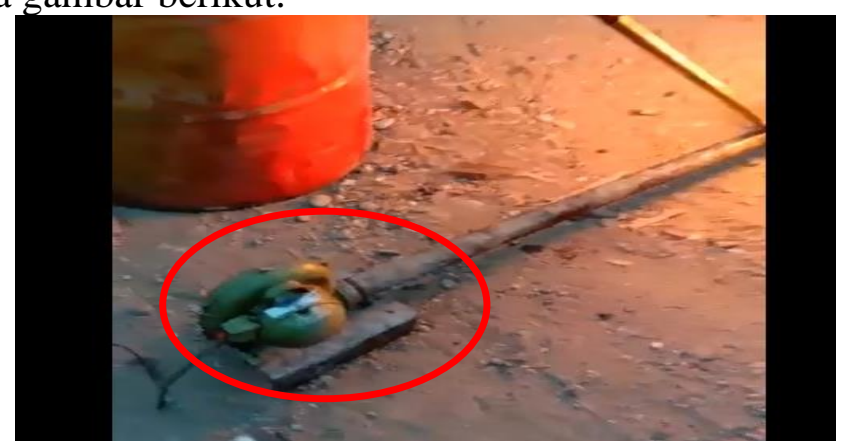

- Langkah 13

Atur kekuatan tiupan angina yang berasal dari blower listrik untuk mendapatkan nyala api yang sempurna. 


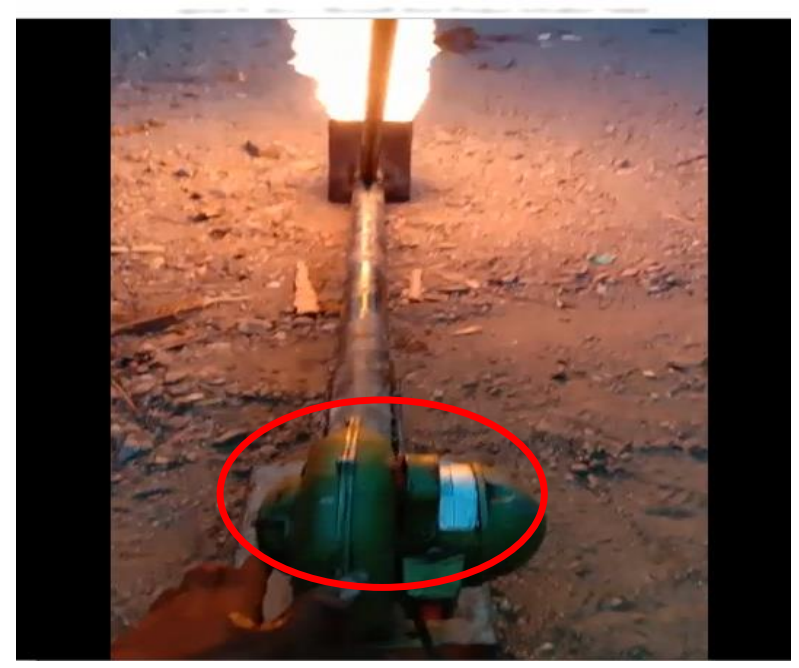

- Langkah 14

Putar keran oli sesuai kebutuhan api yang diinginkan.

\section{Sosialisasi}

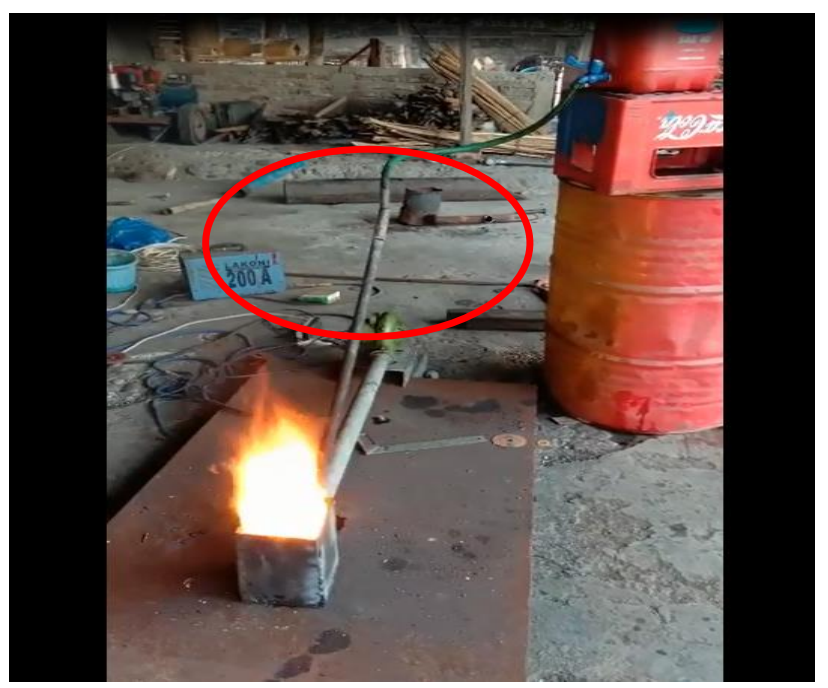

Setelah tahap finalisasi, tahap selanjutnya adalah tahap sosialisasi produk kepada masyarakat. Pada tahap ini sosialisasi dilakukan secara manual dengan tetap memperhatikan protokol kesehatan yang ketat dan juga dilakukan secara daring dengan membuat video promosi dan juga dipromosikan melalui media online.

\section{Survei Akhir}

Pada tahap ini kami evaluasi terhadap produk yang dihasilkan, kelemahan produk, ketertarikan masyarakat menggunakan produk ini dan keterjangkauan masyarakat dalam membeli atau membuat produk ini.

Adapun hasil evaluasi yang kami peroleh, terdapat $85 \%$ orang menyukai produk ini dengan alas an produk ini nsangat praktis, harga jualnya terjangkau, bahan bakar sangat mudah didaptkan dan sangat membantu pekerjaan mereka. 


\section{HASIL DAN PEMBAHASAN}

A. Hasil Yang Dicapai

Pandemi Covid-19 memberikan dampak bagi seluruh kehidupan masyarakat dimana salah satunya adalah mempengaruhi ekonomi masyarakat itu sendiri. Untuk memperbaiki atau memenuhi kebutuhan ekonomi banyak dari masyarakat terutama di daerah kita Manggarai yang selain berprofesi sebagai petani juga banyak yang mulai berternak salah satunya adalah ternak Babi. Makanan atau pakan babi sebagain besarnya harus di masak atau di olah terebih dahulu sebelum diberikan pada ternak dan ini membutuhkan bahan bakar yang banyak. Bahan bakar yang sering digunakan diantaranya adalah minyak tanah dan juga membutuhkan kayu yang banyak sehingga membutuhkan biaya yang mahal pula. Kompor Api berbahan oli bekas (KALIS) adalah suatu teknologi yang secara konseptual mirip dengan kompor liquified petroleum gas alias elpiji yang banyak dijumpai dan digunakan dalam kebutuhan rumah tangga dan industry rumah tangga. Bedanya, Kompor api berbahan oli bekas terdiri dari tangki penampungan oli bekas, selang yang dihubungkan dengan besi yang kemudian dihubungkan dengan burned hedan juga corong angin. Perbedaan lainnya adalah, bahan baku yang digunakan adalah oli bekas sisa pembuangan kendaraan bermotor, yang banyak dijumpai di berbagai bengkel atau tempat reparasi kendaraan bermotor. Corong angin berfungsi untuk memberi tekanan pada oli bekas yang mengalir pada burned head untuk kemudian mempertahankan nyala api. Stop kran yang dipasangkan pada tabung oli bekas berfungsi untuk memberi pilihan alternative volume api yang akan dikeluarkan. Untuk membantu mengenal kompor api berbahan oli bekas tim menggunakan media sosial seperti Facebook dan juga Whatsapp untuk mengenalkan inovasi terbaru ini kepada masyarakat sehingga inovasi ini akan di kenal luas oleh masyarakat.

\section{B. Potensi Pengembangan Usaha}

1. Mudah dalam pembuatan

Pembuatan kompor api berbahan oli bekas ini tidak sulit dikarenakan alat-alat yang digunakan dalam pembuatan KALIS ini mudah untuk didapatkan dan dalam pembuatannya bisa juga menggunakan barang-barang bekas pakai yang ditemukan di lingkungan tempat tinggal ataupun di bekelbengkel.

2. Bahan baku

Bahan baku yang mudah didapatkan yaitu bahan baku yang dibutuhkan dalam menggunakan KALIS ini adalah oli bekas kendaraan atau oli yang sudah tidak di pakai lagi. Oli bekas sangat mudah di dapatkan di bengkelbengkel ataupum diler sehingga untuk bahan baku untuk menggunakan konfor ini tidak sulit untuk di dapatkan karena bahan baku yang banyak dan harganya lebih murah dari bahan bakar seperti minyak tanah dan kayu sehingga tidak memutuhkan biaya yang mahal untuk menggunakan konfor ini. 
3. Menghemat waktu

Berbeda dengan konfor jenis lainnya, salah satu keunggulan dari kompor berbahan oli bekas ini adalah api yang dihasilkan cukup besar sehingga dapat dengan cepat menghasilkan panas, maka proses pematangan juga akan semakin cepat dan sangat cocok untuk membantu dan memudahkan peternak dalam mengolah pakan ternak.

\section{DAFTAR PUSTAKA}

Astuti, Setyani Agung Dwi. 2021. Dampak Covid-19 Terhadap Ketenagakerjaan Dan Umkm Di Mojokerto, Jurnal Inovasi Penelitian Volume 1 nomor 9. https://stp-mataram.e-journal.id/JIP/article/download/236/295/

Dwi, Aditya Putra. 2020.Inflasi 2020 Jadi yang Terendah Akibat Daya Beli Masyarakat Tertekan Pandemi. https://www.liputan6.com/bisnis/read/4448521/inflasi-2020-jadi-yangterendah-akibat-daya-beli-masyarakat-tertekan-pandemi

Haryadi, R. N., Anda Rojali, Khumidin, \& M. Fauzan. (2021). Sosialisasi Penggunaan Online Shop berbasis Website di UMKM Cimanggis. Jurnal Pengabdian Masyarakat Madani (JPMM), 1(1), 10-16. https://doi.org/10.51805/jpmm.v1i1.3

Indah,Puspitasari. 2020. Pengaruh pandemi covid-19 terhadap daya beli masyarakat (studi kasus pada@lashyuk). Undergraduate thesis, Universitas Pembangunan Jaya. http://eprints.upj.ac.id/id/eprint/1133/

Pratama, Annasruddin dkk. 2020. Rancang Bangun Kompor (Burner) Berbahan Bakar Oli Bekas. Mekanika: Majalah Ilmiah Mekanika, Volume 19 nomor 2. file://D:/Data\%20Johan/STIKES\%20SANTU\%20PAULUS/Keperawatan/P KM\%20Mahasiswa/Dokumentasi\%20Kegiatan/42378-114088-3-PB.pdf

Santosa, M. 2020. Analisis Dampak Pandemi Covid 19 Terhadap Perekonomian Lokal Dari Sudut Pandang Jenis Pekerjaan Dan Pendapatan Terhadap Tingkat Daya Beli Masyarakat Di Jawa Tengah. Prepotif: Jurnal Kesehatan $\begin{array}{lllll}\text { Masyarakat } & \text { Volume } & 4 & \text { Nomor }\end{array}$ https://journal.universitaspahlawan.ac.id/index.php/prepotif/article/view/978

Sunarsi, D., et al. (2021). Penyuluhan Wirausaha Untuk Meningkatkan Ekonomi Keluarga Dengan Daur Ulang Barang Bekas Desa Mekarsari Kabupaten Bogor. Jurnal PADMA: Pengabdian Dharma Masyarakat, 1(2). 